\title{
Individual Health Insurance Mandates and Financial Distress: A Few Notes from the Debtor- Creditor Research and Debates
}

\author{
Melissa B. Jacoby
}

Although I am a debtor-creditor researcher and not a health law expert, I could not resist the invitation of Dean Gail Agrawal and Professor Elizabeth Weeks to comment briefly on Massachusetts's recent ambitious efforts to secure universal health insurance coverage, ${ }^{1}$ particularly because Massachusetts is not alone in experimenting with mandates to achieve higher rates of insurance. ${ }^{2}$ My assessments at this time are necessarily tentative; not only am I a relative novice regarding the nation's "most complicated industry,"3 but the Massachusetts

- George R. Ward Professor of Law, University of North Carolina at Chapel Hill. Thanks to Gail Agrawal and Elizabeth Weeks for inviting me to participate in the Symposium on the Massachusetts Plan and the Future of Universal Coverage, Nick Sexton and Michael Shumaker for helping me locate books and reports, and the University of North Carolina School of Law for financial support. Special thanks to Stephen Ware for his thoughtful written response. Although the editing process precluded meaningful reply here, I look forward to engaging with his ideas in future work. This writing is based on my oral remarks at the Symposium. The supporting research was conducted in fall 2006 and winter 2007 and reflects the state of events at that time.

1. An Act Providing Access to Affordable, Quality, Accountable Health Care, ch. 58, 2006 Mass. Acts (forthcoming), available at http://www.mass.gov/legis/laws/seslaw06/sl060058.htm [hereinafter Mass. Plan]. The technical correction bill is An Act Relative to Health Care Access, ch. 324, 2006 Mass. Acts, available at http://www.mass.gov/legis/laws/seslaw06/sl060324.htm [hereinafter Mass. Plan]. A relatively neutral account of the basic components may be found in April Grady, Congressional Research Service, The Massachusetts Health Reform Plan: A Brief Overview, May 26, 2006, http://www.opencrs.com/rpts/RS22447_20060526.pdf.

2. Governor Arnold Schwarzenegger's plan similarly relies on a combination of individual mandates and employer mandates. Press Release, Arnold Schwarzenegger, Governor of Cal., Gov. Schwarzenegger Tackles California's Broken Health Care System, Proposes Comprehensive Plan to Help All Californians (Jan. 8, 2007), available at http://gov.ca.gov/index.php?/press-release/5057/; see also Press Release, Edward G. Rendell, Governor of Penn., Governor Rendell's 'Prescription for Pennsylvania.' Will Ensure Access to Quality Health Care in a Variety of Settings (Jan. 18, 2007), available at http:/www.state.pa.us/papower/cwp/view.asp?A=11\&Q=459427 (discussing health heart proposal). U.S. Senator Ron Wyden's plan uses individual mandates, albeit in a slightly different way, and also cuts the tie between place of employment and source of health insurance coverage. Healthy Americans Act, S. 334, 110 th Cong. (2007); Press Release, Ron Wyden, U.S. Senator, Senator Wyden Leads Federal Debate on Health Care Reform (Jan. 16, 2007), available at http://wyden.senate.gov/media/speeches/2007/01162007_Healthy_Americans.html. Prevailing presidential policy prefers tax incentives rather than penalties to encourage health insurance purchasing. George W. Bush, President of the United States, President's Radio Address (Jan. 20, 2007), available at http://www.whitehouse.gov/news/releases/2007/01/print/20070120.html.

3. See Donald M. Berwick \& Sachin H. Jain, The Basis for Quality Care in Prepaid Group 
legislature left to the Commonwealth Connector Board the task of defining what constitutes an "affordable" plan for people of various incomes, and this limits my ability to comment on those affordability standards in greater detail. ${ }^{4}$

The Commonwealth of Massachusetts could have framed the major policy issue it sought to tackle in terms of escalating medical costs. ${ }^{5}$ Instead, it framed the issue in terms of insurance coverage. Lack of insurance is often used as a proxy for two problems: lack of regularized access to health care delivery systems, ${ }^{6}$ and lack of protection from risk of major financial liabilities. ${ }^{7}$ In other words, covering the uninsured is not so much an end as it is a means to achieve these objectives.

An individual mandate is one of several tools in the Massachusetts Plan to increase the number of citizens with health insurance, and thus

Practice, in TOWARd a $21 \mathrm{st}$ CENTURy Health System: THE CONTRIBUTIONS AND PRomise of Prepaid Group Practice 22, 42 (Alain C. Enthoven \& Laura A. Tollen eds., 2004) (explaining why "[h]ealth care has been called the nation's most complicated industry").

4. The Commonwealth Connector Board is charged with determining when plans are unaffordable such that an individual mandate would be inapplicable; it also is responsible for determining how much, if anything, low-income people should pay for subsidized insurance. See, e.g., Jeffrey Krasner, Senator Says Health Plan Rates Too High: Low-Income Residents Could Be Priced Out By Proposal, He Warns, Boston GLoBE, Aug. 31, 2006 (arguing that Massachusetts "wants to charge too much for health insurance coverage"); BOARD OF THE COMMONWEALTH HEALTH INSURANCE CONNECTOR AUTHORITY, MINUTES OF AUGUST 17, 2006 MEETING (noting that a report from the affordability committee was discussed, but no official position on affordability standards was adopted). At the time of the Symposium, the Board was focused on enrolling the subsidized lowest income citizens. See Commonwealth CARE IMPLEMENTATION Progress REPORT (2006) (discussing the status of "Commonwealth Care" as of Oct. 11, 2006).

5. See generally Edward J. Larson \& Marc Dettman, The Impact of HSAs on Health Care Reform: Preliminary Results After One Year, 40 WAKE FOREST L. REV. 1087, 1089 (2005) (reviewing medical costs).

6. INSTITUTE OF MEdicINE, HIDDEN COSTS, VALUE LOST: UNINSURANCE IN AMERICA 38-93, $105-119$ (2003).

7. See, e.g., Economic Challenges Facing Middle Class Families: Hearing Before the H. Comm. on Ways and Means, 110th Cong. (2007) [hereinafter Economic Challenges Hearing] (Testimony of Diane Rowland, Henry J. Kaiser Family Found.) (identifying delivery and financial risk aspects of health insurance); KATHERINE SWARTZ, REINSURING HEALTH: WHY MORE MIDDLEClass PEOPLe ARE UNINSURed AND What GovernMENT CAN DO 128 (2006) (discussing difficulty of attaining adequate health care delivery for uninsured families); J.P. Ruger, The Moral Foundations of Health Insurance, 100 Q. J. MED. 53, 55 (2007) (discussing the potential risks from being uninsured); see also Christian Nordqvist, Is Massachusetts Health Plan Pure Ideology or Good Economics?, MED. NEwS TODAY, Apr. 16, 2006, http://www.medicalnewstoday.com/ healthnews.php?newsid=41708 (noting that the goal of universal health insurance should not be perceived as purely ideological given the current level of health spending). See generally DAVID M. CUTLER, YOUR MONEY OR YOUR LIFE: STRONG MEdicine FOR AMERICA's HEALTH CARE SySTEM 114 (2004) ("Just about everyone agrees that all people should have health insurance."). 
presumably to address these underlying issues. ${ }^{8}$ This also is a feature of other state and national health care reform proposals. ${ }^{9}$ The individual mandate is a requirement to buy insurance or to pay a financial penalty to be enforced by the state department of revenue. 10 It is a "pay or play" provision of sorts, or, perhaps more accurately, "pay or pay." "The individual mandate cannot prevent Massachusetts's young and healthy residents from moving to New Hampshire or other nearby states to avoid its reach, but it is intended to force them into insurance pools to balance out risk. ${ }^{12}$ The mandate also overrides subjective beliefs about the value of and need for health insurance, which is an issue I will return to at the end of my commentary. ${ }^{13}$

An individual mandate can be somewhat harsh (or perhaps futile) on its own because, among other things, the price of insurance must affect the take-up rate to some extent. ${ }^{14}$ Researchers from across the ideological spectrum likely agree that low-income people lack the financial means to buy many health insurance products regardless of their subjective assessments of its value. ${ }^{15}$ The Massachusetts Plan seeks

8. Mass. Plan, supra note $1, \S 12$.

9. See, e.g., Press Release, Amold Schwarzenegger, supra note 2; Press Release, Ron Wyden, supra note 2 .

10. See Commonwealth Connector, Frequently Asked Questions for Individuals, http://www. mass.gov/?pageID=hicterminal\& $\mathrm{L}=1 \& \mathrm{LO}=$ Home\&sid=Qhic (follow "Commonwealth Choice: Overview" hyperlink) (last visited Jan. 29, 2007) ("Individuals who cannot show proof of health insurance coverage by Dec. 31, 2007, will lose their personal income tax exemption when filing their 2007 income taxes. The 2006 personal exemption is $\$ 3,850$ for an individual, which translates into a tax savings of approximately $\$ 204$ for an individual $(5.3$ percent of $\$ 3,850$ ). Failure to meet the requirement in 2008 will result in a fine for each month the individual does not have coverage. The fine will equal 50 percent of the least costly, available insurance premium that meets the standard for creditable coverage.").

11. See Mass. Plan, supra note 1, at CRS-4 (stating that "those who do not have insurance and are not exempt from the mandate will lose their state income tax personal exemption"). The Commonwealth Connector will be a clearinghouse for plans available for purchase by uninsured individuals. For an explanation of Commonwealth Choice, including plans for young adults, see Commonwealth Connector, Connector Programs, http://www.mass.gov (search for "Commonwealth Connector Programs"; then follow "Connector Programs" hyperlink) (last visited Feb. 3, 2007).

12. Cost-based refusal of insurance coverage by healthier young people is thought to contribute to adverse selection. See SWARTZ, supra note 7, at 129.

13. See generally Sherry Glied, Health Insurance Expansions and the Content of Coverage, in 6 Frontiers IN Health Policy ResearCh 55, 67 (David M. Cutler \& Alan M. Garber eds., 2003) ("Health insurance expansions, then, intend to encourage uninsured people to behave in ways that do not necessarily maximize their subjective utility but rather address specific public-policy objectives.").

14. See, e.g., Michael Chemew et al., Increasing Health Insurance Costs and the Decline in Health Insurance Coverage, 40 HEALTH SERVICES RES. 1021, 1029, 1033-34 (2005) (describing a statistical correlation between premium increases and declines in insurance coverage).

15. As for everyone else, see, for example, Helen Levy \& Thomas DeLeire, What Do People Buy When They Don't Buy Health Insurance and What Does that Say About Why They Are 
to address this by subsidizing the acquisition of certain health insurance products by citizens with incomes at or below $300 \%$ of the poverty level through its Commonwealth Care program. ${ }^{16}$ This component of the Massachusetts Plan was made a priority, and, as of the time of this Symposium, enrollment was underway. ${ }^{17}$ But beyond the lowest income residents, the enforceability of the individual mandate is conditioned on the availability of health plans that are "affordable," which is a term that the enabling legislation did not define. ${ }^{18}$

Let us assume for now that the Massachusetts Plan will decrease the number of uninsured people in the Commonwealth and stabilize the coverage of some who previously cycled through periods of uninsurance. $^{19}$ Let us also assume that, in so doing, the Massachusetts Plan will hook previously uninsured people into health care delivery networks. This still leaves the question of whether the Massachusetts Plan makes progress toward the second underlying goal, which is to protect individuals against financial risk. I refer to this risk more generally as medical-related financial distress. By expending taxpayer resources and requiring greater out-of-pocket outlays from citizens through the individual mandate of the Massachusetts Plan, the Commonwealth of Massachusetts does not necessarily make its citizens

Uninsured 25-28 (Nat'l Bureau of Econ. Research, Working Paper No. 9826, 2003), available at http://papers.nber.org/papers/w9826.pdf (reporting differences in spending habits between insured and uninsured households).

16. Mass. Plan, supra note $1, \S \S 8,45$. For how the existence of Commonwealth Care will affect the available options for low-income Massachusetts residents, see generally MASSACHUSETTS MEDiCAID POLICY INSTITUTE \& U. MASS. MEDICAL SCHOOL CENTER FOR HEALTH POLICY AND Research, Pathways to Public Health insurance Coverage for massachusetts RESIDENTS (Dec. 2006). For a chart of how much low-income people will pay in premiums or copays, see Commonwealth Connector, Commonwealth Care: 4 Plan Types are Offered, http://www. mass.gov/Qhic/docs/CCare_Presentation_FebUpdate.ppt $\$ 420,2$, CommonwealthCare (last visited Mar. 10, 2007). For general eligibility guidelines, see Commonwealth Connector, Commonwealth Care, Goalmind: Eligibililty, https:/www.macommonwealthcare.com/goalmind/login/external/ eligibility.jsp (last visited Mar. 10, 2007). For a justification of a subsidies approach rather than a pure cost containment approach, see, for example, Chernew et al., supra note 14, at 1035.

17. Commonwealth Connector, http://www.myhealthconnector.org (last visited Mar. 10, 2007).

18. See, e.g., John Holahan \& Linda Blumberg, Massachusetts Health Care Reform: A Look at the Issues, 2006 HEALTH AFF.: WEB EXCLUSIVE w432, w436-37 (explaining that the law did not define affordability); COMMISSION ON MEDICAID AND THE UNINSURED, MASSACHUSETTS HEALTH CARE REFORM PLAN (2006), available at http:/www.ktt.org/uninsured/upland/7494.pdf (same); COMMUNity Catalyst InC., MassachusetTs Health Reform: What IT DoEs; How it Was DONE; CHALlENGES AHEAD (Apr. 21, 2006), http://www.communitycatalyst.org/resource.php? base_id=1023 (same).

19. Massachusetts already has a lower uninsured population than many other states. Tom Miller, Massachusetts: More Mirage Than Miracle, 2006 HeAlth AfF.: Web Exclusives w450, w450. 
more financially secure; it might just be shifting around the insecurity, which ultimately may undercut health care delivery goals.

In theory, insurance coverage might reduce the need for bankruptcy, ${ }^{20}$ lessen the reliance on high-priced credit products to smooth health care consumption, cut the demand for debt collectors specializing in self-pay medical receivables, produce declines in state debt collection lawsuits and resulting coercive collection, and reduce credit report notations for medical debt delinquency. Yet, empirical research suggests that being labeled as "insured"-the mere fact of insurance coverage-is not now synonymous with protection from financial risk arising from medical problems, and perhaps never will be. $^{21}$

Some of the most severe financial consequences of medical problems not covered by insurance are indirect, such as lost income and opportunity. $^{22}$ Regarding the direct costs of medical care, bankruptcy and health services research suggests that insurance coverage does not provide complete financial protection. ${ }^{23}$ The first issue is the price of insurance itself. To the extent that rising medical costs send health insurance premiums to less affordable levels, requiring health insurance purchases could increase household financial difficulties rather than

20. See Sherry Glied, Health Insurance Expansions and the Content of Coverage: Is Something Better Than Nothing?, in 6 FRONTIERS IN HEALTH POL'y RES. 55, 72 (David M. Cutler \& Alan M. Garber eds., 2003) (noting that health insurance can protect against the consequences of a common bankruptcy-triggering event, unforeseen illness or accident).

21. For a review of some of the recent data on this point, see Economic Challenges Hearing, supra note 7 (noting that the scope of coverage is often limited and leaves insureds with large out-ofpocket expenses).

22. See Melissa B. Jacoby \& Elizabeth Warren, Beyond Hospital Misbehavior: An Alternative Account of Medical-Related Financial Distress, 100 Nw. U. L. REV. 535, 561 (2006) ("[M]edicalrelated indebtedness is not just a consequence of direct medical bills."). For an example from the medical literature recognizing the need for increased study of indirect costs, see K. Robin Yabroff et al., Burden of Illness in Cancer Survivors: Findings from a Population-Based National Sample, $96 \mathrm{~J}$. NAT'L CANCER INST. 1322, 1322 (2004), stating that "prior research in estimating the burden of cancer in the United States has focused on the direct medical costs of treating illness . . . Other components of cancer burden - productivity and intangible costs - have received less attention." For a report on findings regarding lost days from work among cancer survivors as compared to control group see id. at 1327. As John Colombo has observed, at least one insurance company-AFLAChas recognized a market for insurance against indirect costs. John D. Colombo, Federal and State Tax Exemption Policy, Medical Debt and Healthcare for the Poor, 51 ST. LouIS U. L.J. 433 (forthcoming 2007).

23. The calculation of "under-insurance" is contested. I review the under-insurance and financial burden literature in greater detail in Melissa B. Jacoby, The Debtor-Patient Revisited, 51 ST. LOUIS U. L.J. 293 (2007). 
reduce them. ${ }^{24}$ By imposing an individual mandate without seeking to tackle health care costs, the Massachusetts Plan arguably puts its citizens in a bit of a bind. ${ }^{25}$ As noted earlier, the legislature did not statutorily define "affordability," so it voted in favor of this plan without knowing which citizens would be absolved from the individual mandate on that basis. ${ }^{26}$ As in many other means testing contexts, the details of the affordability determinations are likely to be controversial. ${ }^{27}$ In any event, it remains possible that some households will be more financially stressed from health care costs with the individual mandate in place than without it. In addition, the penalty against an individual for failure to buy insurance is unlikely to be dischargeable if that individual files for bankruptcy. ${ }^{28}$ This increases the significance of relying on individual mandates without also focusing on cost containment.

In addition to the financial impact of insurance premiums, there of course is the impact of out-of-pocket patient obligation (co-pays,

24. For an analysis of 2003 Medical Expenditure Panel Survey data on premium cost and burden, see Jessica S. Banthin \& Didem M. Bernard, Changes in Financial Burdens for Health Care: National Estimates for the Population Younger than 65 Years, 1996 to 2003, 296 JAMA 2712, 2715 tbl.1 (2006). See also SwARTZ, supra note 7, at 4-6 (identifying rising costs of medical care as part of reason lack of insurance among middle class is rising); id. at 125 (discussing rising insurance premiums); David M. Cutler, Employee Costs and the Decline in Health Insurance Coverage, in Frontiers IN HEALth POLICY RESEARCH 28, 35 (David M. Cutler \& Alan M. Garber eds., 2003); Michael Chernew et al., supra note 14, at 1029, 1033-34 (reporting on drops in coverage by increases in premium cost).

25. See, e.g., Steffie Woolhandler \& David U. Himmelstein, Massachusetts Health Reform Bill. A False Promise of Universal Coverage, CommonDreams.org, Apr. 6, 2006, http:/www. commondreams.org/views06/0406-35.htm (discussing the likelihood that many uninsured individuals will not have the means to pay for health care coverage). For an ominous prediction of rising health care costs, see, for example, HENRY J. AARON \& WILLIAM B. SCHWARTZ WITH Melissa Cox, Can We Say no? The Challenge of Rationing health Care 1-2 (2005); SWARTZ, supra note 7, at 4-6.

26. The Commonwealth Connector Board's website includes documents relating to board meetings that suggested some work on the issue, but, as of the time of this Symposium, had not yet resolved it. See, e.g., Memorandum from Bob Carey, Dir. of Planning and Dev., to Commonwealth Health Ins. Connector Authority Bd. (Oct. 12, 2006), available at http:/www.mass.gov/ Qhic/docs/financial_hardship_waiver.doc (discussing difficulty of establishing standards given the inherent subjectivity in what constitutes essential expenses); Memorandum from Jon Kingsdale to Bd. of the Connector, Executive Dir. Of Commonwealth Health Ins. Connector Auth. (Oct. 10, 2006), available at http://www.mass.gov/Qhic/docs/eligibility_memo.doc (discussing recommendations for waivers of certain Plan requirements).

27. For a preview of those debates in the context of the lowest-income citizens, see, for example, Krasner, supra note 4. See generally Holahan \& Blumberg, supra note 18 (analyzing the Massachusetts bill and assessing its potential for success).

28. See 11 U.S.C. $\$ 523(\mathrm{a})(7)$ (2000) (excepting governmental penalties from discharge). The federal individual mandate recently proposed by Senator Ron Wyden explicitly excepts from discharge in bankruptcy the financial penalty for failure to buy insurance. The Healthy Americans Act, S. 334, 110 th Cong. (2007). 
deductibles, caps, exclusions). Insurance is so important in part because of the difficulty of predicting who will encounter catastrophic illness and when. ${ }^{29}$ Yet, the medical expenses encountered by the vast majority of the population in any given year are not catastrophic, and yet many households nonetheless struggle with them, or at least fail to pay them. ${ }^{30}$ Federal Reserve researchers looking at a nationally representative sample of credit reports from the late 1990 s found that $36.5 \%$ of the notations for medical bills were for $\$ 100$ or less and that $70 \%$ were for $\$ 250$ or less. ${ }^{31}$ Only $4.2 \%$ of court judgments that could be identified as medical were for $\$ 5,000$ or more. ${ }^{32}$ Some insurance plans become more "affordable" by shifting more responsibility for medical bills to patients, and thus an individual mandate coupled with an affordability threshold could increase medical debt delinquency.

Smaller unpaid bills may signify policy issues other than inadequately comprehensive health insurance. ${ }^{33}$ According to some researchers, average American households experience large variations in financial status. ${ }^{34}$ This suggests that they may have difficulty absorbing

29. See SWARTZ, supra note 7, at 61-65 (explaining that a large proportion of health expenditures in any given year stems from a very small percentage of individuals, and discussing why it is difficult to predict who will have the highest medical expenses). See generally Leon Wyszewianski, Financially Catastrophic and High-Cost Cases: Definitions, Distinctions, and Their Implications for Policy Formation, 23 INQUIRY 382 (1986) (distinguishing cases considered catastrophic based on a percentage of family income from cases considered high cost based on absolute dollar amount).

30. I review some of the studies and explore the non-catastrophic expense puzzle in another recent symposium contribution. Jacoby, supra note 23.

31. See Robert B. Avery et al., An Overview of Consumer Data and Credit Reporting, 89 FED. RES. BULL., 47, 69 tbl.11 (2003) (reporting actions reported by collection agencies)

32. Id. at 67 tbl.10 (reporting medical judgments grouped by size).

33. Most versions of an optimal universal health care finance system do not envision firstdollar coverage for regular medical needs for non-poor households, although medical expenses can be cumulatively burdensome. See, e.g., AARON \& SCHWARTZ WITH CoX, supra note 25, at 95 (stating that health insurance efficiency is principally intended to protect against the "risk of large and burdensome financial losses"). Some patients may prefer insurance offering comprehensive coverage even for small medical bills. See Glied, supra note 13, at 55 ("front-end coverage with a low-benefit maximum is likely to be perceived as more valuable than catastrophic coverage by lowincome uninsured people"). This preference matches to some extent with the prepaid group practice approach to health care finance and delivery. See, e.g., Alain C. Enthoven, Open the Markets and Level the Playing Field, in TOWARD a 21 ST CENTURY HEALTH SYSTEM: THE CONTRIBUTIONS AND PROMISE OF PREPAID GROUP PRACTICE, supra note 3, at 237 (comparing comprehensive and low cost-sharing features of PGP as compared to consumer driven health plans); Raymond Fink \& Merwyn R. Greenlick, Prepaid Group Practice and Health Care Research, in TOWARD A 21ST Century health System: The Contributions and Promise of Prepaid Group Practice, supra note 3, at 158 (describing common features of PGPs).

34. For research using longitudinal data and finding large proportions of the population having been in poverty or using means tested welfare programs at some point in time, see Mark R. Rank \& Thomas A. Hirschl, Rags or Riches? Estimating the Probabilities of Poverty and Affluence Across 
even small amounts of unexpected medical debt that arise at particular times. In addition, small medical debts may signify a lack of clarity or transparency over the scope of coverage rather than an under-insurance problem per se. Medical providers or their collectors may pursue informal or formal collection against patients who reasonably believe their insurance companies are paying a bigger proportion of bills than they actually do. ${ }^{35}$

Delinquency on smaller medical debts also may be evidence of the absence of well-priced credit products that could smooth consumption for more routine medical liabilities. Households rely, at least to some extent, on credit rather than insurance for other significant and important expenses such as home ownership, cars, and education. These kinds of expenses are not so different from recurring costs of preventive and basic care, to which some of the standard economic explanations for health insurance apply with far less force. ${ }^{36}$ Many of the medical-specific credit

the American Life Span, 82 SOC. SCI. Q. 651, 665-67 (2001) ("half of Americans in the general population will experience poverty during adulthood, half of Americans . . . will experience affluence, and the chances of experiencing one economic extreme versus the other are roughly 50/50."); Mark R. Rank \& Thomas A. Hirschl, The Likelihood of Poverty Across the American Adult Life Span, 44 SOC. WORK 201, 205-11 (1999) (stating poverty statistics for different age groups); Mark R. Rank \& Thomas A. Hirschl, Welfare Use as a Life Course Event: Toward a New Understanding of the U.S. Safety Net, 47 SOC. WORK 237, 240-44 (2002) (noting that two-thirds of Americans between the ages of 20 and 65 will at some point reside in a household that receives welfare benefits). See generally JACOB HACKER, THE GREAT RISK SHIFT 137-63 (2006) (discussing risks in United States healthcare).

35. For myriad cases involving debt collection disputes regarding amounts uncovered by insurance, see, for example, Lockard v. Equifax, Inc., 163 F.3d 1259, 1261-62 (11th Cir. 1998) (involving plaintiff's allegation that his credit report contained medical debts that he did not owe); Spence v. TRW, Inc., 92 F.3d 380, 381 (6th Cir. 1996) (involving a credit report that referenced a debt for medical services that the plaintiff claimed was his insurer's responsibility); Kaplan $v$. Assetcare, Inc., 88 F. Supp. 2d 1355, 1358 (S.D. Fla. 2000) (upholding validity of plaintiff's claim against debt collector that allegedly attempted collection of a medical debt purportedly covered by plaintiff's insurance); Finnegan III v. University of Rochester Medical Center, 21 F. Supp. 2d 223, 228-29 (W.D.N.Y. 1998) (finding that plaintiff had a claim against debt collectors when plaintiff alleged that the collectors had pursued collection of a medical debt that plaintiff had repeatedly disputed); Blake v. Charleston Area Medical Center, Inc., 498 S.E.2d 41, 44.45 (W.Va. 1997) (concerning patient's fraud claim against hospital that won default judgment to collect the portion of patient's medical expenses that insurer did not pay); Victory Memorial Hospital v. Rice, 493 N.E.2d 117, 120 (Ill. App. Ct. 1986) (reversing a directed verdict for the patient in a hospital's suit to recover payment for medical services).

36. See, e.g., Amy B. Monahan, The Promise and Peril of Ownership Society Health Care Policy, 80 TUL. L. REV. 777, 806 (2006) (discussing how, under the classic conception of insurance, preventive care is not an insurable risk). It is not unheard of in health policy to analogize to other consumer expenditures in various ways. Victor Fuchs and Alan Garber analogize insurance for health care to insurance for the purchase of a car. AARON \& SCHWARTZ WITH COX, supra note 25, at 2; see also Victor R. Fuchs \& Alan M. Garber, Health and Medical Care, in AGENDA FOR THE NATION 145, 172-73 (Henry J. Aaron et al. eds., 2003) (analogizing to the purchase of computers). 
products I have seen so far anticipate unrealistically short payoffs or have steep interest rates. ${ }^{37}$ But well-designed credit products issued by, say, community development credit unions, may be a useful supplement to insurance for some kinds of health care consumption-at least in the event that truly comprehensive prepaid group practices fail to take hold again. In any event, whether medical debt delinquency is due to underinsurance, lack of transparency, or the absence of appropriate credit products, it can impose significant emotional distress and adversely affect credit scores, which in turn may affect access to credit, rental housing, and employment. ${ }^{38}$

My musings here suggest that an increased rate of insurance is not an automatic panacea for the underlying issues for which insurance coverage is often used as a proxy. Even assuming it does not itself impose financial pressure on a household, health insurance as it is now known protects against some but not nearly all of the financial risks associated with medical problems. A lack of financial protection can undercut the other underlying goal of covering the uninsured, namely health care delivery. Debtor-patients often report in surveys that medical debt and other financial problems deter them from seeking health care and adhering to prescription drug regimens. ${ }^{39}$

I will end by commenting on another dimension of the discussion of individual mandates to buy health insurance. As noted earlier, the individual mandates are supposed to override subjective beliefs about the value of insurance and to incorporate younger and healthier residents into the risk pool. Some proponents of individual mandates believe they are necessary to combat free riding by those who "choose" more freely to be uninsured, consume health care without paying for it, and impose costs on others. ${ }^{40}$ As in the parallel debates over the cost implications of a

37. See, e.g., Jacoby \& Warren, supra note 22 , at 559-60 (listing various medical-specific credit products).

38. See, e.g., Robert B. Avery et al., Credit Report Accuracy and Access to Credit, 90 FED. RES. BULL. 297, 312, 314-20 (2004) (estimating credit score impact of mistakes regarding medical collection).

39. See, e.g., Jacoby \& Warren, supra note 22, at 582.

40. See, e.g., Press Release, Arnold Schwarzenegger, supra note 2 (employees who turn down coverage contribute to higher costs for those with health insurance); Peter Harbage \& Len M. Nichols, A Premium Price: The Hidden Costs all Californians Pay in our Fragmented Health Care System, NEW AMERICA FOUNDATION 2-4 (Dec. 2006) (unpaid medical bills result in increased costs for those with health insurance). For a refutation of the uninsured-by-choice argument, see Health Access California, An Individual Mandate for Health Insurance: Unwise, Unwarranted, Unworkable, HEALTH ACCESS, Dec. 4, 2006, http://www.health-access.org/expanding/docs/ access.project.Ind.Mandate120406.pdf. The nature of the arguments used to advocate for individual mandates parallel some of strands of the successful advocacy for bankruptcy reform that culminated 
generous bankruptcy system, the scope of the free rider problem is not entirely clear. ${ }^{41}$ In any event, other kinds of laws from the debtorcreditor world could be enlisted to target the behavior thought to be undesirable. For example, federal lawmakers could reduce the dischargeability of medical debts in bankruptcy for younger and more well-off filers. ${ }^{42}$ Although medical debt collection already has significant consequences for individuals of modest means, ${ }^{43}$ states could bolster medical providers' debt collection tools for higher income people. $^{44}$ In addition, consumer financial education-a tool mentioned frequently in debtor-creditor and consumer credit debates-should include insurance topics and not be limited to credit. ${ }^{45}$ Whether

in major changes in 2005. See Bankruptcy Abuse Prevention and Consumer Protection Act of 2005, Pub. L. No. 109-8 § 102, 119 Stat. 23 (2005). In debates and hearings, lawmakers suggested that the American people should object to paying the tax that bankruptcy imposes on households in the form of higher prices on credit, goods, and services. See, e.g., 151 CONG. REC. S2113 (daily ed. Mar. 7, 2005) (statement of Sen. McConnell) ("I rise today on behalf of every American who each year is forced unknowingly to pay a hidden tax. We all know we have to pay an income tax, a sales tax, a payroll tax, but what about a bankruptcy tax? You may not have heard of this tax, but you and every other man, woman, and child in America pay it every single year. . . According to a Department of Justice study, the bankruptcy tax amounts to a staggering $\$ 400$ for every man, woman, and child in America once a year every year.").

41. See, e.g., Miller, supra note 19, at w451 (calling "vastly overstated" the uncompensated care justifications for an individual mandate). Some research illustrates that uncompensated care is not entirely a function of the totally and chronically uninsured. See John Shiels et al., Cost and Coverage Estimates for the "Healthy Americans Act," THE LEWIN GROUP 14 (December 12, 2006) (working paper, on file with The University of Kansas Law Review, http://www.lewin. com/NR/rdonlyres/37BD21 DB-BEFE-4C2F-AFEA-802BDF91EAD7/0/HealthyAmericansAct

Analysis.pdf) (reporting on split of authority on extent of hospital cost-shifting to insured in terms of increased charges); Harbage \& Nichols, supra note 40, at 3 (stating that "there is reason to believe that the underinsured, particularly in California's government programs, contribute significantly to cost-shifting, thereby adding even higher costs to private premiums."); Karoline Mortensen, Emergency Department Utilization of the Intermittently Uninsured, ECON. RES. INITIATIVE ON THE UNINSURED (Aug. 25, 2006) at http://eriu.sph.umich.edu/pdf/conf2006_mortensen.pdf (finding that the combination of uninsured patients and low reimbursement rates from Medicaid beneficiaries are detrimental to a hospital's bottom line).

42. In theory, Congress has furthered this goal by implementing a detailed means test for chapter 7 filers with higher incomes. See 11 U.S.C. $\S 707$ (b)(2). In reality, however, the means test may not be well suited to achieving this goal.

43. See Avery et al., supra note 38, at 318-20 (discussing the impact of medical collection on credit score); A Review of Hospital Billing and Collection Practices: Hearing Before the Subcomm. on Oversight and Investigations, 108th Cong. 107 (2004) (testimony of Prof. Melissa B. Jacoby) (discussing the various negative effects of medical debt on modest income families in the context of bankruptcy).

44. See Jacoby \& Warren, supra note 22, at 565-570 (reporting on special debt collection entitlements for medical service providers under various state laws).

45. See generally Geeta Menon et al., Health Risk Perceptions and Consumer Psychology, in HANDBOOK OF CONSUMER PSYCHOLOGY (Curtis Haugtvedt et al. eds.) (forthcoming); SWARTZ, supra note 7, at 36 ("Interviews indicate that most view health insurance premiums as high relative to their expected medical expenses. It was striking that those under age forty spoke about health insurance as if it were prepaid medical care. They seemed to ignore the fact that insurance would 
independent of or in conjunction with a mandate, these kinds of steps could increase the extent to which citizens value health insurance and their willingness to pay into the health care system. 
*** 